\title{
Production and nutritional value of the wheat silage managed with different cutting systems
}

\section{Produção e qualidade nutricional da silagem de trigo manejado em diferentes sistemas de corte}

\author{
Rodolfo Carletto $^{1 *}$; Mikael Neumann²; Danúbia Nogueira Figueira ${ }^{1}$; \\ Guilherme Fernando Mattos Leão ${ }^{4}$; Egon Henrique Horst ${ }^{3}$; \\ Antônio Vinícius Iank Bueno ${ }^{4}$; Tânia Mara Becher Ribas³; Cecília Aparecida Spada ${ }^{1}$
}

\begin{abstract}
Winter cereals are mainly used for human and animal nutrition and several studies are now exploring their potential as conserved forage (hay and silage). Among the winter cereal species available for cultivation in the south of Brazil, which is major winter cereals producer in the country, the wheat cv. BRS Umbu has attracted special attention. However, few studies have investigated the potential of this cultivar for silage production. The aim of this study was to evaluate the production and quality of silage from the dual-purpose wheat, BRS Umbu, subjected to different cut managements treatments: $\mathrm{T}_{1}$ - without cut (control), $\mathrm{T}_{2}$ - one cut and $\mathrm{T}_{3}$ - two cuts. Each plot represented an experimental unit in a randomized block design, with 5 replicates per treatment. Two representative samples were collected from each plot to determine morphological segmentation (stem, leaf and ear) and dry matter (DM) content of the whole plant and its morphological components. At the time of opening of the silos, food chemical analysis and $\mathrm{pH}$ determination were performed. Forage mass production decreased by $26.88 \%$ and $67.82 \%$, respectively, with one and two cuts, compared to control. The DM content of the ensiled plant was $49.9 \mathrm{~g} \mathrm{~kg}^{-1}$ for the control, $54.7 \mathrm{~g} \mathrm{~kg}^{-1}$ with one cut and $63.2 \mathrm{~g} \mathrm{~kg}^{-1}$ with two cuts, at the time of ensiling. Management cuts changed the morphological components of the plants, with a lower proportion of stem (28\%) in plants subjected to two cuts. The control treatment showed fewer leaves in ensiled plant (9.6\%) and intermediate amount of stalk (52.8\%), and was significantly different $(\mathrm{p}<0.05)$ to treatment of a cut. Regarding feed chemistry evaluations, no significant difference $(\mathrm{p}>$ 0.05 ) was observed for mineral matter (MM), crude protein (CP) and hemicellulose (HEM) between the different cutting regimens. However, neutral detergent fiber (NDF) and acid detergent fiber (ADF) decreased $(\mathrm{p}<0.05)$ as the number of cuts increased. The control treatment showed higher NDF and ADF content (563.2 and $357.9 \mathrm{~g} \mathrm{~kg}^{-1} \mathrm{DM}$, respectively) and lower amount of total digestible nutrients (TDN) and net energy of lactation $\left(\mathrm{NE}_{\mathrm{L}}\right)$. However, the estimated milk production (EMP) was superior for this treatment $\left(22,447 \mathrm{~h} \mathrm{ha}^{-1}\right)$, demonstrating the high impact of reduced forage mass production with increased number of cuts.
\end{abstract}

Key words: Feed chemical composition analysis. Ensiling. Pasture management. Morphology.

\footnotetext{
${ }^{1}$ Mestres em Agronomia, Universidade Estadual do Centro-Oeste, UNICENTRO, Guarapuava, PR, Brasil. E-mail: rodolfocarletto@hotmail.com; danmedvet07@gmailcom; spadacecilia@hotmail.com

2 Prof. Dr., Universidade Estadual do Centro-Oeste, UNICENTRO, Guarapuava, PR, Brasil. E-mail: neumann.mikael@hotmail.com

${ }^{3}$ Médico Veterinário, Universidade Estadual do Centro-Oeste, UNICENTRO, Guarapuava, PR, Brasil. E-mail: egonhh@yahoo. com.br; taniamarabecherribas@hotmail.com

${ }^{4}$ Mestres em Zootecnia, Universidade Estadual de Maringá, UEM, Maringá, PR, Brasil. E-mail: gfleão@hotmail.com; antonio. iank.bueno@gmail.com

* Author for correspondence
} 


\section{Resumo}

O cultivo de cereais de inverno tem como objetivo suprir a demanda alimentar humana e animal, contudo estudos recentes têm focado no seu uso como alimento conservado (feno e silagem). Dentre as várias opções disponíveis para o plantio o trigo cv. BRS Umbu vem despertando interesse. Contudo, poucos estudos tem avaliado o potencial desta cultivar para produção de silagem. Sendo assim, objetivo deste trabalho foi avaliar a produção e a qualidade das silagens obtidas a partir do trigo de duplo propósito, BRS Umbu, manejado em diferentes manejos de cortes: $\mathrm{T}_{1}-$ sem corte (controle), $\mathrm{T}_{2}-$ um corte e $\mathrm{T}_{3}$ - dois cortes. Cada parcela representou uma repetição em um delineamento em blocos casualizados, com cinco repetições por tratamento. Duas amostras representativas de cada parcela foram coletadas para se determinar a composição morfológica e massa seca dos seus componentes. No momento da abertura dos silos, amostras foram coletadas para determinação do $\mathrm{pH}$ e composição nutricional. $\mathrm{O}$ aumento no número de cortes proporcionou redução na produção de massa de forragem seca na ordem de $26.88 \%$ e $67.82 \%$ do manejo com um e dois cortes, respectivamente em relação ao controle. No momento da ensilagem o teor de matéria seca (MS) das plantas ensiladas foi de 49,9 para o tratamento sem corte, $54,7 \mathrm{~g} \mathrm{~kg} \mathrm{MS}^{-1}$ para o tratamento com um corte e $63,2 \mathrm{~g} \mathrm{~kg} \mathrm{MS}^{-1}$ para o tratamento com dois cortes. Verificou-se alterações nos componentes morfológicos das plantas, sendo influenciados pelo manejo de cortes, observando-se menor proporção de colmo nas plantas submetidas a dois cortes (28\%), porém, apresentando maior proporção de espigas $(59,4 \%)$, enquanto o tratamento controle mostrou menor quantidade de folhas nas plantas ensiladas $(9,6 \%)$ e quantidade intermediária de espigas $(52,8 \%)$, diferindo $(\mathrm{P}<0,05)$ do tratamento de um corte, que apresentou $(42,6 \%)$ de espigas na planta. Para as avaliações bromatológica não foram observadas diferença significativa $(\mathrm{P}>0,05)$ para matéria mineral $(\mathrm{MM})$, proteína bruta $(\mathrm{PB})$ e hemicelulose (HEM), No entanto, fibra em detergente neutro (FDN) e fibra em detergente ácido (FDA) foram reduzidos $(\mathrm{P}<0,05)$ com o aumento dos cortes, sendo que o tratamento controle mostrou a maior média tratamento sem cortes $(563,3$ e 357,9 g.kg-1 MS) e menores teores de nutrientes digestíveis totais $(\mathrm{NDT})$ e energia líquida de lactação $\left(\mathrm{EL}_{\mathrm{L}}\right)$. Todavia, a produção estimada de leite (PL) mostrou superioridade para este tratamento $\left(22.4471 \mathrm{ha}^{-1}\right)$, demonstrando o alto impacto da redução da produção de massa de forragem seca com o aumento do número de cortes.

Palavras-chave: Composição química. Ensilagem. Manejo de Pastagem. Morfologia.

\section{Introduction}

The South of Brazil is a major agricultural region, particularly for grain production, and is responsible for $36.5 \%$ of the total grain production in the country. The states of Paraná and Rio Grande do Sul account for $17.9 \%$ and $15.9 \%$ of the total Brazilian grain production, respectively, and are the larger producers of winter cereals in Brazil (BRASIL, 2016).

The main use of winter cereals is for human and animal nutrition. They can also be a source of roughage for ruminants, mostly as herbage (BUMBIERIS JÚNIOR et al., 2011) but, due to production fluctuation in a pasture, reducing the impact of the feed is necessary. Accordingly, an increasing number of studies have evaluated the potential of winter cereals as conserved forage (hay and silage). These feeds can be used as roughage supplementation when there is a lack of forage, or as an ingredient in diets to increase animal production (SCHEFFER-BASSO et al., 2003).

Of the many winter cereal species available for cultivation, wheat (Triticum sativum L.) deserves emphasis due to its high productivity of forage mass and grains. Fontaneli et al. (2009) compared 6 winter cereal species for silage production and observed an average dry matter yield of 5,056 kg.ha ${ }^{-1}$, and a grain yield of $1,984 \mathrm{~kg} \cdot \mathrm{ha}^{-1}$ for wheat.

Among wheat cultivars appropriate for silage production, BRS Umbu has attracted attention due 
to its large dry matter productivity, which reaches up to 10 tons per hectare. Further, the panicles in this cultivar lack awns, and thus do not cause irritation of the esophageal mucosa (HASKELL, 2011; LEHMEN et al., 2014). This cultivar also displays high grain yield, reaching 3,468 kg.ha-1 (MEINERZ et al., 2011), which is of interest as this plant fraction has great energy content. Moreover, high concentrations of crude protein (up to $83 \mathrm{~g} . \mathrm{kg}^{-}$

$1 \mathrm{DM}$ ) have been reported in BRS Umbu silage (LEHMEN et al., 2014). Therefore, further studies evaluating this cultivar for silage production are of interest.

This study aimed to evaluate the effect of cutting management of the wheat cultivar BRS Umbu on silage yield and quality.

\section{Material and Methods}

The study was conducted at the Animal Production Center (NUPRAN), at Universidade Estadual do Centro-Oeste (UNICENTRO), Guarapuava, Paraná, Brazil (2523'02'S 5129'43' $\mathrm{W}, 1,026 \mathrm{~m}$ elevation). The climate in the region is considered $\mathrm{Cfb}$ (subtropical mesothermal humid) according to the Köppen classification, with mild summers and winters, no dry season and with severe frosts. The mean annual rainfall is 1,944 $\mathrm{mm}$; the average annual minimum and maximum temperatures are $12.7^{\circ} \mathrm{C}$ and $23.5^{\circ} \mathrm{C}$, respectively. Average annual relative humidity is $77.9 \%$ (IAPAR, 2000).

The soil of the experimental field is typical brown latosol (POTT et al., 2007) and had the following chemical composition at the time of sowing ( 0 to $20 \mathrm{~cm}$ profile): $\mathrm{pH}\left(\mathrm{CaCl}_{2} 0.01 \mathrm{M}\right)$ : 4.7; P: $1.1 \mathrm{mg} . \mathrm{L}^{-1} ; \mathrm{K}^{+}: 0.2 \mathrm{cmol}_{\mathrm{c}} \cdot \mathrm{L}^{-1}$; Organic Matter: $2.62 \% ; \mathrm{Al}^{3+}: 0.0 \mathrm{cmol} \cdot \mathrm{L}^{-1} ; \mathrm{H}^{+} \mathrm{Al}^{3+}: 5.2$ $\mathrm{cmol}_{\mathrm{c}} \cdot \mathrm{L}^{-1} ; \mathrm{Ca}^{2+}: 5.0 \mathrm{cmol}_{\mathrm{c}} \cdot \mathrm{L}^{-1} ; \mathrm{Mg}^{2+}: 5.0 \mathrm{cmol}_{\mathrm{c}} \cdot \mathrm{L}^{-1}$; and base saturation: $67.3 \%$.
The wheat cultivar tested was BRS Umbu (Triticum aestivum L.), which is characterized as a double purpose cultivar. Treatments consisted of the different cut regimes: $\mathrm{T}_{1}$ - no cutting (control treatment); $\mathrm{T}_{2}$ - one cutting; $\mathrm{T}_{3}$ - two cuttings.

The total area of the experimental field was 225 $\mathrm{m}^{2}$, divided in 15 plots of $15 \mathrm{~m}^{2}$ each $(3 \mathrm{~m} \times 5 \mathrm{~m})$, with the evaluations occurring in a $8 \mathrm{~m}^{2}(2 \mathrm{~m} \mathrm{x} 4$ $\mathrm{m})$ net plot. Each plot represented an experimental unit in a randomized block design, with 5 replicates per treatment. Wheat was sowed on July 13, 2011 in a tillage system. The sowing density was of 220 seeds per $\mathrm{m}^{2}$, with $0.17 \mathrm{~m}$ spacing between drills and sowing depth of $0.04 \mathrm{~m}$.

NPK $\left(\mathrm{N}-\mathrm{P}_{2} \mathrm{O}_{5}-\mathrm{K}_{2} \mathrm{O}\right)$ fertilizer (04-20-20) was applied at $400 \mathrm{~kg} \cdot \mathrm{ha}^{-1}$ as recommended by (CQFS$\mathrm{RS} / \mathrm{SC}, 2004)$. Nitrogen topdressing at $390 \mathrm{~kg} \cdot \mathrm{ha}^{-1}$ $\mathrm{N}$ (45-00-00) in the form of urea was performed in two occasions: thirty days after sowing (140 $\mathrm{kg} \cdot \mathrm{ha}^{-1}$ ) and thirty days after the first application $\left(250 \mathrm{~kg} \cdot \mathrm{ha}^{-1}\right)$. The same pest management protocol was used in all treatments, according to need, as determined by a technical report.

Harvesting to a standard height of $8 \mathrm{~cm}$ (FONTANELI et al., 2009) was performed manually with a scythe in the net plot $\left(8 \mathrm{~m}^{2}\right)$ when the plant height reached $30 \mathrm{~cm}$. The ratio of weight of the harvested material per area was calculated cumulatively, allowing an estimate of the forage productivity $\left(\mathrm{kg} \cdot \mathrm{ha}^{-1}\right)$ on a fresh-weight, dry matter and grain-weight bases.

Two representative samples of $500 \mathrm{~g}$ each were collected from each plot to determine morphological segmentation (stem, leaf and ear) and dry matter content (DM) of the whole plant and its morphological components, after drying in a forced air furnace at $55^{\circ} \mathrm{C}(\mathrm{AOAC}, 1995)$.

The plants from the control area were designated only for ensiling. The cut management for the 
other two treatments (one and two cuts) occurred on August 8, 2011, 57 days after planting (DAP). For the two cuts treatment, a second harvest occurred at 105 DAP, when the wheat reached an average height of $30 \mathrm{~cm}$. The cut management was performed as described by Fontaneli et al. (2009) and ensiling was performed when plants were at the same reproductive stages (dough grain stage) for all treatments. Silage was manually produced, in experimental PVC pipe silos (100 mm diameter and $50 \mathrm{~cm}$ height), sealed with a plastic cover and adhesive tape and labeled, staying closed for 60 days.

At the time of opening of the silos, two $500 \mathrm{~g}$ samples of the ensiled material were collected, one for food chemical analysis, and the other for $\mathrm{pH}$ determination (CHERNEY; CHERNEY, 2003). Dry matter was determined according to (AOAC, 1995). After drying, the samples were grounded in a Willey grinder with $1 \mathrm{~mm}$ sieve. Total dry matter, crude protein (CP) and mineral matter (MM) were determined as described by Silva and Queiroz (2009).

Neutral detergent fiber (NDF) was determined using $\alpha$ amylase (Termamyl 120L, Novozymes Latin America Ltda.) according to Van Soest et al. (1991), acid detergent fiber (ADF) according to Goering and Van Soest (1970), and lignin (LIG) as in Dettman et al. (2012). The hemicellulose (HEM) content was calculated using the formula HEM = FDN - FDA (SILVA; QUEIROZ, 2009).

Total digestible nutrient content (TDN) was calculated with the equation TDN $\left(\mathrm{g}^{\mathrm{kg}} \mathrm{kg}^{-1} \mathrm{DM}\right)=$ $((87.84-(0.70 \times$ FDA $)) \times 100)($ BOLSEN, 1996) . The net energy of lactation values $\left(\mathrm{NE}_{\mathrm{L}}\right)$ was obtained with the equation $\mathrm{NE}_{\mathrm{L}}\left(\mathrm{Mcal}_{\mathrm{kg}}{ }^{-1} \mathrm{DM}\right)=$ $0.0245 \times$ TDN $\left({\left.\mathrm{g} . \mathrm{kg}^{-1} \mathrm{DM}\right)}^{-0.12}(\mathrm{NRC}, 2001)\right.$.

The experimental followed a randomized block design. The data were analyzed using analysis of variance (ANOVA) at 5\% significance level in SAS Statistical Software (1993).

\section{Results and Discussion}

Table 1 shows the data for fresh and dry matter yield for the different treatments. As described by Rosário et al. (2012), wheat ensiling should occur when the plant reaches the dough grain stage. Cutting management increased the plant vegetative cycle, delaying harvest time, which occurred 144, 156 and 174 DAP for the control, $\mathrm{T}_{1}$ (one cut) and $\mathrm{T}_{2}$ (two cuts) treatments, respectively.

The highest $(p<0.05)$ production of fresh forage and dry matter was observed without cut management $\left(21,913 \mathrm{~kg} \cdot \mathrm{ha}^{-1}\right.$ and 10,926 kg.ha ${ }^{-1}$, respectively). The crop cut frequency increased concomitantly with an increase in production, on both fresh and dry matter bases.

Table 1. Forage Mass yield (on fresh and dry matter bases) of BRS Umbu wheat subjected to different cutting management treatments.

\begin{tabular}{ccc}
\hline Cutting & \multicolumn{2}{c}{ Forage Mass Yield, kg.ha ${ }^{-1}$} \\
\cline { 2 - 3 } Management & Fresh & Dry matter \\
\hline Control & $21,913 \mathrm{a}$ & $10,926 \mathrm{a}$ \\
One cut & $14,625 \mathrm{~b}$ & $7,989 \mathrm{~b}$ \\
Two cuts & $5,294 \mathrm{c}$ & $3,514 \mathrm{c}$ \\
Mean & 13,944 & 7,476 \\
SEM & 1,850 & 851 \\
P $>$ F & 0.0001 & 0.0001 \\
\hline
\end{tabular}

Means followed by lowercase letters differ among rows $(\mathrm{p}<$ $5 \%$ ), according to Tukey's test.

Our results are similar to the ones obtained for BRS Umbu wheat by Meinerz et al. (2011), who reported average dry matter yield of $10,577 \mathrm{~kg} \mathrm{ha}^{-1}$. However, Fontaneli et al. (2009) reported a lower dry matter yield $\left(6,017 \mathrm{~kg} \mathrm{ha}^{-1}\right)$ for BRS Umbu wheat managed with one cut before ensiling.

Cutting leads to a reduction in the production of photo assimilates by the plant due to the 
removal of tissue capable of photosynthesis, which consequently retards the reestablishment of photosynthesis to normal rates (PARSONS et al., 1988). Depending on the intensity and frequency of cutting, forage mass accumulation may decrease. In our study, this factor impacted the morphological composition of the wheat (Table 2).

The dry matter content of wheat and of its morphological components were higher when the crop was managed with two cuts before ensiling. These results may be due to an increase in the length of the wheat physiological cycle after cutting management.

Furthermore, a reduction in stem proportion and an increase in ear production were observed after the two cuts treatment. Cutting stimulates tillering and, over time, leads to an increase in the number of viable tillers in a compensatory manner, which can lead to a greater ear (and consequently grain) yield (SANGOI et al., 2011; FIOREZE; RODRIGUEZ, 2012).

Plants that suffer no tillering stimulation tend to favor development of the main stem (SANGOI et al., 2011), consistent to what was observed for the control and the one cut treatments. Leaf yield was highest under one cut management.

The greater participation of the ears in the morphological composition led to an increase (40.31\% above control) of dry matter content of silages from the crop treated with two cuts. On the other hand, cut management did not affect ( $p>0.05)$ $\mathrm{pH}, \mathrm{MM}$, or CP contents (Table 3).

Table 2. Morphological composition and dry matter content at the time of ensiling of BRS Umbu (whole plants and separated components) subjected to different cutting management treatments.

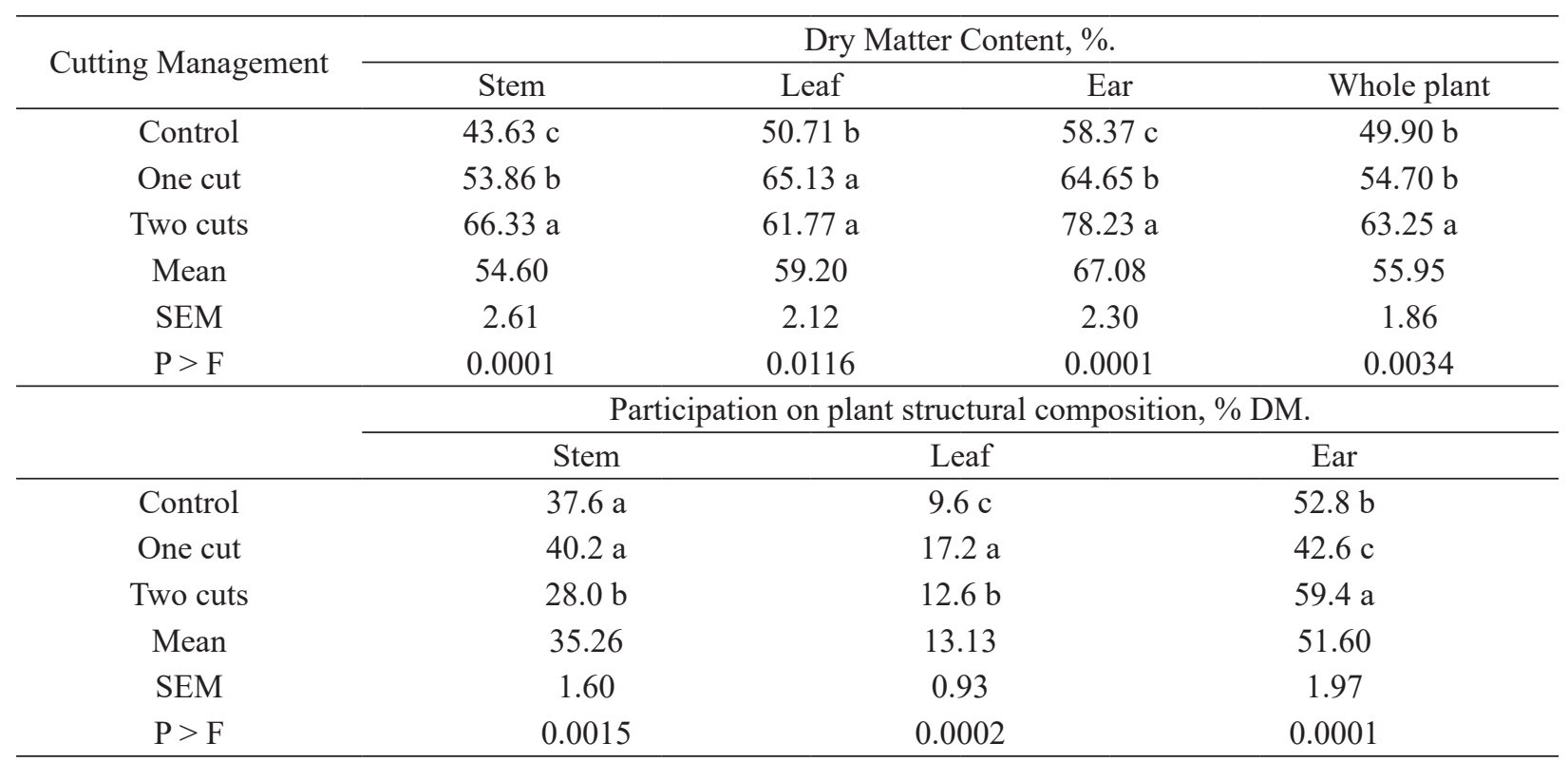

Means followed by lowercase letters differ among rows $(\mathrm{p}<5 \%)$, according to Tukey’s test. 
Table 3. Mean contents of dry matter (DM), mineral matter (MM), crude protein (CP), and $\mathrm{pH}$ of BRS Umbu wheat silages subjected to different cutting management treatments.

\begin{tabular}{ccccc}
\hline Cutting Management & $\mathrm{DM}\left(\mathrm{g} \cdot \mathrm{kg}^{-1} \mathrm{NM}\right)$ & $\mathrm{MM}\left(\mathrm{g} \cdot \mathrm{kg}^{-1} \mathrm{DM}\right)$ & $\mathrm{CP}\left(\mathrm{g} \cdot \mathrm{kg}^{-1} \mathrm{DM}\right)$ & $\mathrm{pH}$ \\
\hline Control & $453.2 \mathrm{c}$ & $48.9 \mathrm{a}$ & $74.9 \mathrm{a}$ & $4.41 \mathrm{a}$ \\
One cut & $543.9 \mathrm{~b}$ & $33.3 \mathrm{a}$ & $72.0 \mathrm{a}$ & $4.43 \mathrm{a}$ \\
Two cuts & $635.9 \mathrm{a}$ & $39.7 \mathrm{a}$ & $77.8 \mathrm{a}$ & $4.41 \mathrm{a}$ \\
Mean & 544.4 & 40.6 & 74.9 & 4.41 \\
SEM & 22.04 & 4.93 & 5.83 & 0.04 \\
P $>$ F & 0.0003 & 0.5463 & 0.9460 & 0.9761 \\
\hline
\end{tabular}

Means followed by lowercase letters differ among rows $(\mathrm{p}<5 \%$ ), according to Tukey's test.

The NDF, ADF and LIG contents declined $(\mathrm{p}<$ 0.05 ) as the number of cuts increased, whereas HEM did not change between treatments (Table 4). As the plant progresses to physiological maturity, there is a tendency to accumulate cell wall components and a loose soluble nutrients content (VAN SOEST,
1994). However, the greater participation of grains in forage mass due to cut management decreased the fiber content. Grains contains high amounts of structural carbohydrates, and increasing their participation in forage mass leads to a reduction of fiber content due to a dilution effect.

Table 4. Mean contents of neutral detergent fiber (NDF), acid detergent fiber (ADF), hemicellulose (HEM) and lignin (LIG) of BRS Umbu wheat silages subjected to different cutting management treatments.

\begin{tabular}{ccccc}
\hline \multirow{2}{*}{ Cutting Management } & NDF & ADF & HEM & LIG \\
\cline { 3 - 5 } & & \multicolumn{2}{c}{${\mathrm{g} \cdot \mathrm{kg}^{-1} \mathrm{DM}}$} \\
\hline Control & $563.2 \mathrm{a}$ & $357.9 \mathrm{a}$ & $205.2 \mathrm{a}$ & $43.3 \mathrm{a}$ \\
One cut & $480.5 \mathrm{~b}$ & $291.0 \mathrm{~b}$ & $210.6 \mathrm{a}$ & $56.8 \mathrm{a}$ \\
Two cuts & $469.5 \mathrm{~b}$ & $256.3 \mathrm{~b}$ & $205.0 \mathrm{a}$ & $26.7 \mathrm{~b}$ \\
Mean & 504.4 & 301.7 & 206.9 & 42.3 \\
SEM & 16.32 & 13.90 & 10.36 & 3.78 \\
P $>$ F & 0.0104 & 0.0009 & 0.9739 & 0.0015 \\
\hline
\end{tabular}

Means followed by lowercase letters differ among rows $(\mathrm{p}<5 \%)$, according to Tukey's test.

The reduction of fiber content led to an increase $(\mathrm{p}<0.05)$ in silage TDN and $\mathrm{NE}_{\mathrm{L}}$ as the number of cuts increased (Table 5). This effect is related to the decline in silage ADF in crops subjected to one or two cuts treatments. This cell wall fraction affects forage digestibility (VAN SOEST et al., 1991). On the other hand, the potential milk yield decreased for the silage from crops subjected to either of the cut treatments compared to control due to the reduction of dry matter yield.

Meinerz et al. (2011), evaluated silages from winter cereals subjected to cut management and reported lignin content of 41.7 g. $\mathrm{kg}^{-1} \mathrm{DM}$ and hemicellulose content of 278 g. $\mathrm{kg}^{-1}$ DM for BRS Umbu wheat silage. For other wheat cultivars, these values ranged from 49.3 to $51.9 \mathrm{~g} \mathrm{~kg} \mathrm{DM}^{-1}$ for lignin, and 254.7 to $295.7 \mathrm{~g} \mathrm{~kg} \mathrm{DM}^{-1}$ for hemicellulose. The same authors observed values of $555.9 \mathrm{~g} \mathrm{~kg} \mathrm{DM}^{-1}$ for NDF corrected for ash, and $320.6 \mathrm{~g} \mathrm{~kg} \mathrm{DM}^{-1}$ for ADF corrected for ash, in BRS Umbu wheat silages. These values are similar to those found in the present study. 
Table 5. Estimated values of total digestible nutrients (TDN, g. $\mathrm{kg}^{-1} \mathrm{DM}$, net energy of lactation $\left(\mathrm{NE}_{\mathrm{L}}, \mathrm{Mcal}_{\mathrm{kg}} \mathrm{kg}^{-1}\right.$ DM) and potential milk yield (PMY, kg.ha-1) per hectare of BRS Umbu wheat silages subjected to different cutting management treatments.

\begin{tabular}{|c|c|c|c|}
\hline Cutting & TDN & $\mathrm{NE}_{\mathrm{L}}$ & PMY \\
\hline Management & g. $\mathrm{kg}^{-1} \mathrm{MS}$ & Mcal.kg-1 & L.ha $^{-1}$ \\
\hline Control & $627.8 \mathrm{~b}$ & $1.418 \mathrm{~b}$ & $22.447 \mathrm{a}$ \\
\hline One cut & $670.8 \mathrm{a}$ & $1.523 \mathrm{a}$ & $17.616 \mathrm{~b}$ \\
\hline Two cuts & $680.8 \mathrm{a}$ & $1.548 \mathrm{a}$ & $7.533 \mathrm{c}$ \\
\hline Mean & 659.8 & 1.496 & 15.865 \\
\hline SEM & 7.79 & 0.02 & 1700.54 \\
\hline $\mathrm{P}>\mathrm{F}$ & 0.0003 & 0.0003 & 0.0001 \\
\hline
\end{tabular}

Means followed by lowercase letters differ among rows $(\mathrm{p}<$ $5 \%$ ), according to Tukey's test.

\section{Conclusions}

Cutting management led to morphological changes, and consequently altered the nutritional composition of silage from BRS Umbu wheat. The lowest contents of neutral detergent fiber, acid detergent fiber and lignin were observed in silages from the crop subjected to the two cuts treatment. Consequently, these silages presented the greatest contents of total digestible nutrients and the highest net energy of lactation.

Our results suggest that cut management before ensiling should be avoided to prevent significant reductions in crop yield on the bases of fresh and dry matter, which can directly impact potential milk yield.

\section{References}

ASSOCIATION OF OFFICIAL ANALYTICAL CHEMISTS - AOAC. Official methods of analysis. $16^{\text {th }}$ ed. Washington, DC: AOAC, 1995. 2000 p.

BOLSEN, K. K. Silage technology. In: AUSTRALIAN MAIZE CONFERENCE, 2., 1996, Queensland. Proceedings... Queensland: Gatton College, 1996. p. $1-30$.

BRASIL, INSTITUTO BRASILEIRO DE GEOGRAFIA E ESTATÍSTICA - IBGE. Estatistica da produção agrícola brasileira (Janeiro). Indicadores
IBGE, Brasília, DF, p. 1-76, 2016. Available at: $<\mathrm{ftp}$ //ftp.ibge.gov.br/Producao_Agricola/Fasciculo_ Indicadores_IBGE/estProdAgr_201601.pdf $>$. Accessed at: 06 june 2015 .

BUMBIERIS JÚNIOR, V. H.; OLIVEIRA, M. R.; JOBIM, C. C.; BARBOSA, M. A. A. F.; CASTRO, L. M.; BARBERO, R. P. Perspectivas para uso de silagem de cereais de inverno no Brasil. In: SIMPÓSIO: PRODUÇÃO E UTILIZAÇÃO DE FORRAGENS CONSERVADAS, 2011, Maringá. Anais... Maringá: Nova Stampha, 2011. p. 39-72.

CHERNEY, J. H.; CHERNEY, D. J. R. Assessing silage quality. In: BUXTOU, D. R.; MUCK, R. E.; HARISSON, J. H. (Ed.). Silage Science and Technology. Madison, Wisconsin: University of Wisconsin, 2003. p. 141-198.

COMISSÃO DE QUÍMICA E FERTILIDADE DO SOLO RS/ SC - CQFS-RS/SC. Manual de adubação e de calagem para os Estados do Rio Grande do Sul e de Santa Catarina. 10. ed. Porto Alegre, RS: Sociedade Brasileira de Ciência do Solo, 2004. 400 p.

DETMANN, E.; SOUZA, M. A.; VALADARES FILHO, S. C. Métodos para análise de alimentos. Visconde do Rio Branco: Universidade Federal de Viçosa, 2012. 214 p.

FIOREZE, S. L.; RODRIGUES, J. D. Perfilhamento do trigo em função da aplicação de regulador vegetal. Revista Brasileira de Ciências Agrárias, Recife, v. 7, p. 750755, 2012.

FONTANELI, R. S.; FONTANELI, R. S.; SANTOS, H. P. dos.; NASCIMENTO JUNIOR, A. do; MINELLA. E.; CAIERÃO, E. Rendimento e valor nutritivo de cereais de inverno de duplo propósito: forragem verde e silagem ou grãos. Revista Brasileira de Zootecnia, Viçosa, MG, v. 38, n. 11, p. 2116-2120, 2009.

GOERING, H. K.; VAN SOEST, P. J. Forage fiber analysis: apparatus reagents, procedures and some applications. Washington, DC: Agricultural Handbook, 1970. 379 p.

HASKELL, S. R. R. Blackwell's five-minute veterinary consult ruminant. Ames, Iowa: Wiley-Blackwell, 2008, $3502 \mathrm{p}$.

INSTITUTO AGRONÔMICO DO PARANÁ - IAPAR. Cartas climáticas do Paraná. Versão 1. 0. Londrina, 2000. CD-ROM.

LEHMEN, R. I.; FONTANELI, R. S.; FONTANELI, R. S.; SANTOS, H.P . Rendimento, valor nutritivo e características de silagens de cereais de inverno. Ciência Rural, Santa Maria, v. 44, n. 7, p. 1180-1185, 2014. 
MEINERZ, G. R.; OLIVO, J. C.; VIÉGAS, J.; NÖRNBERG, J. L.; AGNOLIN, C. A.; CHEIBLER, R. B.; HORST, T.; FONTANELI, R. S. Silagem de cereais de inverno submetidos ao manejo de duplo propósito. Revista Brasileira de Zootecnia, Viçosa, MG, v. 40, n. 10, p. 2097-2104, 2011.

NATIONAL RESEARCH COUNCIL - NRC. Nutrients requirements of dairy cattle. $7^{\text {th }}$ ed. Washington: National Academy Press, 2001. 381 p.

PARSONS, A. J.; PENNING, P. D. The effect of the duration of regrowth on photosynthesis, leaf death and the average rate of growth in a rotationally grazed sward. Grass and Forage Science, Weinheim, v. 43, n. 1, p. 1527, 1988.

POTT, C. A.; MÜLLER, M. M. L.; BERTELLI, P. B. Adubação verde como alternativa agroecológica para recuperação da fertilidade do solo. Revista Ambiência, Guarapuava, v. 3, n. 2, p. 51-63, 2007.

ROSÁRIO, J. G. do; NEUMANN, M.; UENO, R. K.; MARCONDES, M. M.; MENDES, M. C. Produção e utilização de silagem de trigo. Revista Brasileira de Tecnologia Aplicada nas Ciências Agrárias, Guarapuava, PR, v. 5, n. 1, p. 207-218, 2012.
SANGOI, L.; SCHWEITZER, C.; SILVA, P. R. F.; SCHMITT, A.; VARGAS, V. P.; CASA, R. T.; SOUZA, C. A. Perfilhamento, área foliar e produtividade do milho sob diferentes arranjos espaciais. Pesquisa Agropecuária Brasileira, Brasília, v. 46, p. 609-616, 2011.

SCHEFFER-BASSO, S. M.; DURR, J. W.; FONTANELI, R. S. Valor nutritivo de forragens: concentrados, pastagens e silagens. Passo Fundo, RS: Universidade de Passo Fundo, Centro de Pesquisa em Alimentação, 2003. $31 \mathrm{p}$.

SILVA, D. J.; QUEIROZ, A. C. Análise de alimentos: métodos químicos e biológicos. 3. ed. $4^{\mathrm{a}}$ Reimp. Viçosa, MG: Universidade Federal de Viçosa, 2009. 235 p.

STATISTICAL ANALYSIS SYSTEM INSTITUTE SAS Institute. SAS/STAT user's guide statistcs. $4^{\text {th }}$ ed. Version 6. Cary: Inc, 1993. v. 2, 943 p.

VAN SOEST, P. J. Nutritional ecology of the ruminant. $2^{\text {th }}$ ed. Ithaca: Cornell Univ. Press, 1994. 476 p.

VAN SOEST, P. J.; ROBERTTSON, J. B.; LEWIS, B. A. Methods for dietary fiber, neutral detergent fiber, and nonstarch polysaccharides in relation to animal nutrition, Journal of Dairy Science, Savoy, v. 74, n. 10, p. 35833597, 1991. 